\title{
Adult Stem Cells and Cardiac Regeneration
}

\author{
Kursad Turksen
}

Published online: 19 June 2013

(C) Springer Science+Business Media New York 2013

\begin{abstract}
There is worldwide demand for therapies to promote the robust repair and regeneration with maximum regain of function of particular tissues and organs damaged by disease or injury. The potential role of adult stem cells has been highlighted by an increasing number of in vitro and in vivo studies. Nowhere is this more evident than in adult stem cell-based therapies being explored to promote cardiac regeneration. In spite of encouraging advances, significant challenges remain.
\end{abstract}

Keywords Cardiac · Adult stem cells · Regeneration · Mesechymal stem cells $\cdot$ Clinical trials

With an ever-increasing interest in actualizing the regenerative potential of adult stem cells, studies exploring the utility of adult stem cells in tissue and organ regeneration have also intensified [1-10]. Observations from both in vitro and in vivo studies have been encouraging to the point that it is expected that stem cells will become a critical player in regenerative medicine for many diseases and conditions. While there is reason for optimism, sometimes daunting challenges remain vis-à-vis identification of the most effective cell sources, improvement of transplant delivery methods and achieving sustained or functional integration of transplanted cells at injured sites before any of these observations can be efficiently translated to the clinical setting [11]. Nowhere is the optimism and challenge more acute than in the realm of cardiac repair.

Cardiovascular diseases damage the heart, resulting in loss of cardiac function, and contributing to the high cardiovascular-related incidence of morbidity and mortality

\section{K. Turksen $(\triangle)$}

Regenerative Medicine Program, Sprott Centre for Stem Cell

Research, Ottawa Hospital Research Institute, 501 Smyth Road, Ottawa, ON K1H 8L6, Canada

e-mail:kursadturksen@gmail.com worldwide $[12,13]$ The soaring incidence of cardiovascular disease, coupled with the limited availability and challenges of organ transplants, has driven many to look to stem cell therapy as a practical and attractive alternative. The optimism had been fueled by the exciting and compelling increase in our understanding of cardiac cells, their lineage and maturation sequence, and regulation of their function [14-17]. However, with the increased knowledge has come increased understanding of the scope of the challenges. For example, how epigenetic changes regulate and modify not just normal development but contribute to disease states and capacity of stem cells to contribute to organ regeneration is only beginning to be explored [18]. More broadly, understanding of how to achieve sustained repair of damaged cardiac tissue via stimulation of endogenous stem cells or use of transplanted stem cells is still relatively limited [12, 19-21]. Nevertheless, as the papers within a recent special issue of Stem Cell Reviews and Reports (2013 \#3) document, there remains reason for optimism and continued study.

Amongst areas of intense interest are those related to exploring and identifying potential cell populations suitable for repair of injured cardiac tissue, be it repair by donor cells themselves or induction of endogenous cells or combinations of the two. Some approaches are focusing on developing and improving isolation, ex vivo expansion, and manipulation of appropriate cells for excellent engraftment and capacity to promote endogenous cardiac repair [22-27]. The identification of subpopulations of stem cells within cardiac tissue itself has provided new perspectives around patient-specific protocols for cardiac diseases [28-32]. This approach is aligned with the more general approach being studied of how to tap into the crucial cell types that participated in cardiac development originally. Other cell types being explored for cell-based therapy include bone marrowderived mononuclear cells, bone marrow-derived mesenchymal stem cells, cardiac-derived c-kit + stem cells and 
cardio sphere-derived cells. For any of these cell types to become valuable in a clinical setting, it is imperative that they are well characterized. Thus, significant efforts are going towards characterization of the multiple cell populations of interest, including characterization of their stemness and self-renewal capacity, their differentiation potential into functional cell types, and their responsiveness to various regulators and activators.

Activation and/or differentiation of putative stem and precursor cell populations via various signaling factors is an area of intense interest. Recent studies with epicardialresident stem cells, which are known to differentiate into cardiomyocytes during cardiac development in response to certain factors available at appropriate developmental times, underscore the excitement. For example, thymosin beta 4, a peptide critical for cardiac development and with cardioprotective properties, was recently shown to induce differentiation of epicardium-derived progenitor cells (EPDCs) into cardiomyocytes in the adult heart of a small animal model of myocardial infarction, but the data also suggest that there is a distinct window of opportunity for it to be effective [33].

Amongst the various stem and progenitor cell types being investigated, mesenchymal stem cells (MSCs) are one of the most popular [34]. MSCs or MSC-like cells have been derived from a variety of sources including bone marrow and umbilical cord blood. They have been widely tested in preclinical studies and several clinical trials have evaluated their efficacy in cardiac repair. However, the specific role(s) of MSCs in cardiac repair remains unclear and, as noted above, it is likely that it is MSC-cardiac cell interactions that are important. While there remains intense interest and ongoing studies, to date the clinical application of MSCs for mainstream cardiovascular use has been hindered by several important limitations, including suboptimal retention, engraftment and survival and restricted capacity for bona fide cardiomyocyte regeneration. The question of which stem cells are best for a given type of injury or any cardiac injury is an important and challenging one [35]. Head-to-head comparisons of different cell types are still relatively rare. However, in one such study, cardiac stem cells were found to be superior to MSCs in modulating the electrophysiological abnormality and improving the ventricular fibrillation threshold in rats with myocardial infarction [36].

Cardiac disease and the need for cardiac repair is often accompanied by co-morbidities that may influence the outcomes. For example, diabetes is recognized as an important risk factor for peripheral arterial disease, but little is not known about how type II diabetes affects the therapeutic function of adult stem cells, including MSCs. The impact of type II diabetes on the therapeutic efficacy of MSCs in revascularization after the induction of hindlimb ischemia has been investigated using experimental type II diabetes in $\mathrm{db} / \mathrm{db}$ mice. It was observed that diabetes impaired MSCs' therapeutic function by favoring their differentiation towards adipocytes, while limiting their differentiation towards endothelial cells as a consequence of oxidative stress [37]. Although it is not known yet whether the human systems act the same way, it does point towards a therapeutic approach in which reversing the oxidative stress prior to MSC transplantation may be useful [37].

Tissue engineering with specialized scaffolds, with or without stem or progenitor cells, is another approach to providing personalized solutions to the problem of cardiac muscle repair. Inclusion of stem cells with newer classes of composite materials has emerged to take advantage of the benefits of the strengths and minimize the weaknesses of both synthetic and natural materials [38-41]. New developments to fabricate synthetic and hybrid scaffolds to be employed as cell delivery systems and the acknowledgement that surface physical, mechanical, chemical properties can exert specific effects on stem cells appear to be very exciting areas for further studies. In this respect, a cardiac-specific scaffold favoring stem cell electromechanical coupling with host tissue, while also promoting the vascularization of the newly formed tissue, is of interest [42]. Such biomimetic approaches, combined with ability to comply with cardiac muscle architecture, and deformability to sustain cardiac contraction are relevant and worth further investigation.

While preclinical research has advanced into early phase clinical trials in patients, few late-phase clinical trials have been conducted. Sources of donor stem cells, autologous versus allogeneic cell sources, types or lineages of cells, remain critically important considerations [43]. It has been noted that public perception of stem cell therapy as well as manufacturing challenges and the regulatory environment all contribute to the small number of late phase (Phase 3) clinical trials undertaken to date and the lack of Food and Drug Administration (FDA) approvals in the US [43]. Nevertheless, there is progress being made and some data with mixed cell populations are interesting. For example, Aastrom Biosciences has developed a proprietary cellprocessing technology, ixmyelocel- $\mathrm{T}$, a patient-specific multicellular therapy based on expansion of cells from a small sample of a patient's own bone marrow [43, 44]. Ixmyelocel$\mathrm{T}$ uses current good manufacturing practices to expand the MSCs and macrophages. The rationale is that the mixture of expanded MSCs and activated macrophages promotes longterm tissue repair of ischemic tissue. Clinical trial data collected to date support the potential for ixmyelocel-T as an efficacious and safe treatment for ischemic cardiovascular indications, including critical limb ischemia and a severe form of heart failure, dilated cardiomyopathy (DCM). The CLI 
clinical program has completed phase 2 and agreement has been reached for an FDA-approved phase 3 study (REVIVE) through the Special Protocol Assessment process [43-46].

In summary, great interest in stem cell therapies remains but so too do challenges. It is notable that while data are accumulating from basic and translational work that point to the beneficial effects of stem cell therapy, the mechanisms involved in stem cell therapy remain unclear and much preclinical work has not been translated into humans. Hopefully, the studies presented in a recent volume will spur additional work towards addressing the challenges.

Acknowledgments A special thank you goes to Jane Aubin for critically reading this commentary.

\section{References}

1. Anversa, P., Kajstura, J., Rota, M., \& Leri, A. (2013). Regenerating new heart with stem cells. The Journal of Clinical Investigation, 123(1), 62-70. doi:10.1172/JCI63068. Epub 2013 Jan 2.

2. Steinert, A. F., Rackwitz, L., Gilbert, F., Nöth, U., \& Tuan, R. S. (2012). Concise review: the clinical application of mesenchymal stem cells for musculoskeletal regeneration: current status and perspectives. Stem Cells Translational Medicine, 1(3), 237-247. doi:10.5966/sctm.2011-0036. Epub 2012 Feb 22. Review. PubMed PMID: 23197783.

3. Yokote, S., \& Yokoo, T. (2013). Organogenesis for kidney regeneration. Current Opinion in Organ Transplantation, 18(2), 186190. doi:10.1097/MOT.0b013e32835f070d. Review. PubMed PMID: 23425787.

4. Kumar, A., \& Brockes, J. P. (2012). Nerve dependence in tissue, organ, and appendage regeneration. Trends in Neurosciences, 35(11), 691-699. doi:10.1016/j.tins.2012.08.003. Epub 2012 Sep 16. Review. PubMed PMID: 22989534.

5. Atala, A. (2012). Tissue engineering of reproductive tissues and organs. Fertility and Sterility, 98(1), 21-29. doi:10.1016/ j.fertnstert.2012.05.038. Review. PubMed PMID: 22748231.

6. Atala, A. (2012). Regenerative medicine strategies. Journal of Pediatric Surgery, 47(1), 17-28. doi:10.1016/j.jpedsurg.2011.10.013. PubMed PMID: 22244387.

7. Ishikawa, T., Banas, A., Teratani, T., Iwaguro, H., \& Ochiya, T. (2012). Regenerative cells for transplantation in hepatic failure. Cell Transplantation, 21(2-3), 387-399. doi:10.3727/ 096368911X605286. Review. PubMed PMID: 22793046.

8. Rennert, R. C., Sorkin, M., Garg, R. K., \& Gurtner, G. C. (2012). Stem cell recruitment after injury: lessons for regenerative medicine. Regenerative Medicine, 7(6), 833-850. doi:10.2217/ rme.12.82. Review. PubMed PMID: 23164083; PubMed Central PMCID:PMC3568672.

9. Chimenti, I., Forte, E., Angelini, F., Giacomello, A., \& Messina, E. (2012). From ontogenesis to regeneration: learning how to instruct adult cardiac progenitor cells. Progress in Molecular Biology and Translational Science, 111, 109-137. doi:10.1016/B978-0-12398459-3.00005-8. Review. PubMed PMID: 22917228.

10. Templin, C., Kränkel, N., Lüscher, T. F., \& Landmesser, U. (2011). Stem cells in cardiovascular regeneration: from preservation of endogenous repair to future cardiovascular therapies. Current Pharmaceutical Design, 17(30), 3280-3294. Review. PubMed PMID:21919874.
11. Lin, H. T., Otsu, M., \& Nakauchi, H. (2013). Stem cell therapy: an exercise in patience and prudence. Philosophical Transactions of the Royal Society of London. Series B, Biological Sciences, 368(1609), 20110334. doi:10.1098/rstb.2011.0334. Review. PubMed PMID: 23166396.

12. Ellison, G. M., Nadal-Ginard, B., \& Torella, D. (2012). Optimizing cardiac repair and regeneration through activation of the endogenous cardiac stem cell compartment. Journal of Cardiovascular Translational Research, 5(5), 667-677. Epub 2012 Jun 12. Review. PubMedPMID: 22688972.

13. Sheng, C. C., Zhou, L., \& Hao, J. (2013). Current stem cell delivery methods for myocardial repair. BioMed Research International, 2013, 547902. doi:10.1155/2013/547902. Epub Dec 27. PubMed PMID: 23509740; PubMed Central PMCID: PMC3591183.

14. Kikuchi, K., \& Poss, K. D. (2012). Cardiac regenerative capacity and mechanisms. Annual Review of Cell and Developmental Biology, 28, 719-741. doi:10.1146/annurev-cellbio-101011-155739. Review. PubMed PMID: 23057748; PubMed Central PMCID: PMC3586268.

15. Van Vliet, P., Wu, S. M., Zaffran, S., \& Pucéat, M. (2012). Early cardiac development: a view from stem cells to embryos. Cardiovascular Research, 96(3), 352-362. doi:10.1093/cvr/cvs270. Epub 2012 Aug 14. Review. PubMed PMID: 22893679; PubMedCentral PMCID: PMC3500045.

16. Lescroart, F., \& Meilhac, S. M. (2012). Cell lineages, growth and repair of the mouse heart. Results and Problems in Cell Differentiation, 55, 263-289. doi:10.1007/978-3-642-30406-4 15. Review. PubMed PMID: 22918812.

17. Kattman, S. J., Adler, E. D., \& Keller, G. M. (2007). Specification of multipotential cardiovascular progenitor cells during embryonic stem cell differentiation and embryonic development. Trends in Cardiovascular Medicine, 17(7), 240-246. Review.PubMed PMID: 17936206.

18. Vinci, M. C., Polvani, G., Pesce, M. (2012). Epigenetic programming and risk: the birth place of cardiovascular disease? Stem Cell Reviews, [Epub ahead of print]PubMed PMID: 22773406.

19. Mazhari, R., \& Hare, J. M. (2012). Translational findings from cardiovascular stem cell research. Trends in Cardiovascular Medicine, 22(1), 1-6. doi:10.1016/j.tcm.2012.05.017. Review. PubMed PMID: 22940024.

20. Suncion, V. Y., Schulman, I. H., \& Hare, J. M. (2012). Concise review: the role of clinical trialsin deciphering mechanisms of action of cardiac cell-based therapy. Stem Cells Translational Medicine, 1(1), 29-35. doi:10.5966/sctm.2011-0014. Epub 2011 Dec 7. Review. PubMed PMID: 23197637.

21. Choi, Y. H., Saric, T., Nasseri, B., Hühn, S., Van Linthout, S., Hetzer, R., Tschöpe, C., \& Stamm, C. (2011). Cardiac cell therapies: the next generation. Cardiovascular Therapeutics, 29(1), 216. doi:10.1111/j.1755-5922.2010.00191.x. Epub 2010 Oct 14. Review. PubMed PMID: 20946322.

22. Unno, K., Jain, M., \& Liao, R. (2012). Cardiac side population cells: moving toward the center stage in cardiac regeneration. Circulation Research, 110(10), 1355-1363. doi:10.1161/ CIRCRESAHA.111.243014. Review. PubMed PMID: 22581921; PubMed Central PMCID: PMC3412159.

23. Nelson, T. J., Faustino, R. S., Chiriac, A., Crespo-Diaz, R., Behfar, A., \& Terzic, A. (2008). CXCR4+/FLK-1+ biomarkers select a cardiopoietic lineage from embryonic stem cells. Stem Cells, 26(6), 1464-1473. doi:10.1634/stemcells.2007-0808. Epub 2008 Mar 27. PubMed PMID: 18369102.

24. Smits, A. M., van Oorschot, A. A., \& Goumans, M. J. (2012). Isolation and differentiation of human cardiomyocyte progenitor cells into cardiomyocytes. Methods in Molecular Biology, 879, 339-349. doi:10.1007/978-1-61779-815-3_20. PubMed PMID: 22610569.

25. Ferreira-Martins, J., Ogórek, B., Cappetta, D., Matsuda, A., Signore, S., D'Amario, D., Kostyla, J., Steadman, E., Ide-Iwata, N., Sanada, F., 
Iaffaldano, G., Ottolenghi, S., HosodaT, L. A., Kajstura, J., Anversa, P., \& Rota, M. (2012). Cardio-myogenesis in the developing heart is regulated by c-kit-positive cardiac stem cells. Circulation Research, 110(5), 701-715. doi:10.1161/CIRCRESAHA.111.259507. Epub 2012 Jan 24. PubMed PMID: 22275487; PubMed Central PMCID: PMC3292662.

26. Hosoda, T. (2012). C-kit-positive cardiac stem cells and myocardial regeneration. American Journal of Cardiovascular Disease, 2(1), 58-67. Epub 2011 Dec 15. PubMed PMID: 22254215; PubMedCentral PMCID: PMC3257153.

27. Gunetti, M., Noghero, A., Molla, F., Staszewsky, L. I., de Angelis, N., Soldo, A., Russo, I., Errichiello, E., Frasson, C., Rustichelli, D., Ferrero, I., Gualandris, A., Berger, M., Geuna, M., Scacciatella, P., Basso, G., Marra, S., Bussolino, F., Latini, R., \& Fagioli, F. (2011). Ex vivo-expanded bone marrow CD34(+) for acute myocardial infarction treatment: in vitro and in vivo studies. Cytotherapy, 13(9), 1140-1152. doi:10.3109/14653249.2011.597559. Epub 2011 Aug 17. PubMed PMID: 21846293.

28. Frati, C., Savi, M., Graiani, G., Lagrasta, C., Cavalli, S., Prezioso, L., Rossetti, P., Mangiaracina, C., Ferraro, F., Madeddu, D., Musso, E., Stilli, D., Rossini, A., Falco, A., Angelis, A. D., Rossi, F., Urbanek, K., Leri, A., Kajstura, J., Anversa, P., Quaini, E., \& Quaini, F. (2011). Resident cardiac stem cells. Current Pharmaceutical Design, 17(30), 3252-3257. Review.PubMed PMID: 22114897.

29. Koudstaal, S., Jansen Of Lorkeers, S. J., Gaetani, R., Gho, J. M., van Slochteren, F. J, Sluijter, J. P., Doevendans, P. A., Ellison, G. M., Chamuleau, S. A. (2013). Concise review: heart regeneration and the role of cardiac stem cells. Stem Cells Translational Medicine, May 8. [Epub ahead of print] PubMed PMID: 23658251.

30. Hou, J., Wang, L., Jiang, J., Zhou, C., Guo, T., Zheng, S., Wang, T. (2012). Cardiac stem cells and their roles in myocardial infarction. Stem Cell Reviews, Dec 13. [Epub ahead of print] PubMed PMID: 23238707.

31. Weil, B. R., \& Canty, J. M. (2013). Stem cell stimulation of endogenous myocyte regeneration. Clinical Science (London, England), 125(3), 109-119. doi:10.1042/CS20120641. PubMed PMID:23577634.

32. Aguirre, A., Sancho-Martinez, I., \& Izpisua Belmonte, J. C. (2013). Reprogramming toward heart regeneration: stem cells and beyond. Cell Stem Cell, 12(3), 275-284. doi:10.1016/ j.stem.2013.02.008. PubMed PMID: 23472869.

33. Gajzer, D. C., Balbin, J., Chaudhry, H. W. (2012). Thymosin $\beta 4$ and cardiac regeneration: are we missing a beat? Stem Cell Reviews, May 25. [Epub ahead of print] PubMed PMID: 22628110.

34. Richardson, J. D., Nelson, A. J., Zannettino, A. C., Gronthos, S., Worthley, S. G., Psaltis, P. J. (2012). Optimization of the cardiovascular therapeutic properties of mesenchymalstromal/ stem cells-taking the next step. Stem Cell Reviews, Apr 13. [Epub ahead of print] PubMed PMID: 22529015.

35. Cashman, T. J., Gouon-Evans, V., Costa, K. D. (2012). Mesenchymal stem cells for cardiac therapy: practical challenges and potential mechanisms. Stem Cell Reviews, May11. [Epub ahead of print] PubMed PMID: 22577007

36. Zheng, S. X., Weng, Y. L., Zhou, C. Q., Wen, Z. Z., Huang, H., Wu, W., Wang, J. F., Wang, T. (2012). Comparison of cardiac stem cells and mesenchymal stem cells transplantation on the cardiac electrophysiology in rats with myocardial infarction. Stem Cell Reviews, Apr 28. [Epub ahead of print] PubMed PMID: 22544360.

37. Yan, J., Tie, G., Xu, T. Y., Cecchini, K., Messina, L. M. (2013). Mesenchymal stem cells as a treatment for peripheral arterial disease: current status and potential impact of type II diabetes on their therapeutic efficacy. Stem Cell Reviews, Mar 9. [Epub ahead of print] PubMed PMID: 23475434.

38. Cheema, F. H., Polvani, G., Argenziano, M., \& Pesce, M. (2012). Combining stem cells and tissue engineering in cardiovascular repair - a step forward to derivation of novel implants with enhanced function and self-renewal characteristics. Recent Patents on Cardiovascular Drug Discovery, 7(1), 10-20. Review. PubMed PMID: 22280334.

39. Stephanopoulos, N., Ortony, J. H., \& Stupp, S. I. (2013). Self-assembly for the synthesis of functional biomaterials. Acta Materialia, 61(3), 912-930. PubMed PMID:23457423; PubMed Central PMCID: PMC3580867.

40. Segers, V. F., \& Lee, R. T. (2011). Biomaterials to enhance stem cell function in the heart. Circulation Research, 109(8), 910-922. doi:10.1161/CIRCRESAHA.111.249052. Review. PubMed PMID: 21960724.

41. Sreejit, P., \& Verma, R. S. (2013). Natural ECM as biomaterial for scaffold based cardiac regeneration using adult bone marrow derived stem cells. Stem Cell Reviews, 9(2), 158-171. doi:10.1007/s12015-013-9427-6. PubMed PMID: 23319217.

42. Forte, G., Pagliari, S., Pagliari, F., Ebara, M., Di Nardo, P., Aoyagi, T. (2011). Towards the generation of patient-specific patches for cardiac repair. Stem Cell Reviews, Oct 18. [Epub ahead of print] PubMed PMID: 22006278.

43. Bartel, R. L., Booth, E., Cramer, C., Ledford, K., Watling, S., Zeigler, F. (2013). From bench to bedside: review of gene and cell-based therapies and the slow advancement into phase 3 clinical trials, with a focus on Aastrom's Ixmyelocel-T. Stem Cell Reviews, Mar 1. [Epub ahead of print] PubMed PMID: 23456574.

44. Bartel, R. L., Cramer, C., Ledford, K., Longcore, A., Parrish, C., Stern, T., Watling, S., \& Zeigler, F. (2012). The Aastrom experience. Stem Cell Research \& Therapy, 3(4), 26. [Epub ahead of print] PubMed PMID: 22776246; PubMed Central PMCID: PMC3580464.

45. Powell, R. J., Marston, W. A., Berceli, S. A., Guzman, R., Henry, T. D., Longcore, A. T., Stern, T. P., Watling, S., \& Bartel, R. L. (2012). Cellular therapy with Ixmyelocel-T to treat critical limb ischemia: the randomized, double-blind, placebo-controlled RESTORE-CLI trial. Molecular Therapy, 20(6), 1280-1286. doi:10.1038/mt.2012.52. Epub Mar 27. PubMed PMID: 22453769; PubMed Central PMCID: PMC3369291.

46. Powell, R. J., Comerota, A. J., Berceli, S. A., Guzman, R., Henry, T. D., Tzeng, E., Velazquez, O., Marston, W. A., Bartel, R. L., Longcore, A., Stern, T., \& Watling, S. (2011). Interim analysis results from the RESTORE-CLI, a randomized, double-blind multicenter phase II trial comparing expanded autologous bone marrow-derived tissue repair cells and placebo in patients with critical limb ischemia. Journal of Vascular Surgery, 54(4), 1032-1041. doi:10.1016/ j.jvs.2011.04.006. Epub 2011 Jul 31. PubMed PMID: 21684715. 